\title{
Baryancistrus demantoides and Hemiancistrus subviridis, two new uniquely colored species of catfishes from Venezuela (Siluriformes: Loricariidae)
}

\author{
David C. Werneke*, Mark H. Sabaj**, \\ Nathan K. Lujan*, and Jonathan W. Armbruster***
}

Baryancistrus demantoides and Hemiancistrus subviridis are two new species of loricariids from southern Venezuela with an olive ground coloration and white to cream-colored or golden-yellow spots. Baryancistrus demantoides is known only from the upper río Orinoco drainage while H. subviridis is also known from the río Casiquiare drainage. In addition to its coloration, $B$. demantoides can be distinguished from all other ancistrins by having the dorsal and adipose fins connected by an expanded posterior section of the dorsal-fin membrane, golden-yellow spots confined to the anterior portion of the body, and greater than 30 teeth per jaw ramus. Hemiancistrus subviridis can be separated from all other ancistrins by coloration, lacking a connection between the dorsal and adipose fins and having less than 30 teeth per jaw ramus.

Baryancistrus demantoides e Hemiancistrus subviridis são duas espécies novas de loricariídeos do sul da Venezuela, de cor de fundo verde-oliva e manchas brancas a creme ou amarelo-douradas. Baryancistrus demantoides é conhecida somente da bacia do rio Orinoco superior, enquanto $H$. subviridis é também conhecida da bacia do rio Casiquiare. Além da coloração, $B$. demantoides pode ser distinguido de todos os outros ancistríneos por ter as nadadeiras dorsal e adiposa conectadas por uma secção posterior expandida da membrana da nadadeira dorsal, manchas amarelo-douradas restritas à porção anterior do corpo, e mais de 30 dentes por ramo mandibular. Hemiancistrus subviridis pode ser separado de todos os outros ancistríneos pela falta de uma conecção entre as nadadeiras dorsal e adiposa e por possuir menos de 30 dentes por ramo mandibular.

Key words: Ancistrini, Catfish, Hypostominae, Neotropics, South America

\section{Introduction}

The Loricariidae, which is confined to tropical Central and South America, is the largest family of catfishes in the world. Although fishes have been collected in South America for over 300 years, many areas of the continent remain poorly sampled or unsampled. Between 2003 and 2005 researchers from Auburn University, the Academy of Natural Sciences of Philadelphia, and Universidad Nacional Experimental de Los Llanos Occidentales Ezequiel Zamora made three expeditions to Amazonas state of Venezuela, an area previously with only isolated sampling for fishes. The expeditions yielded over 25 putatively new species within the family Loricariidae. Two of the new species from the Subfamily Hypostominae, Tribe Ancistrini, collectively referred to as amarillo-verdes by local inhabitants, have a color pattern unique within the Loricariidae.
The amarillo-verdes have an olive base color with white to cream-colored or golden-yellow spots on the head, body, and fins (Fig. 1).

Baryancistrus is readily recognizable from all other described ancistrins except Parancistrus and Spectracanthicus by the presence of an enlarged posterior membrane of the dorsal fin that is usually connected to the adipose fin (except in B. longipinnis). The described species of Baryancistrus are from the Xingu and Tocantins rivers of Brazil (southern tributaries of the Amazon). Armbruster (2004) did not find any compelling synapomorphies for Baryancistrus; however, $B$. demantoides lacks the synapomorphies for Spectracanthicus and Parancistrus and is assigned to Baryancistrus following the diagnosis of Rapp Py-Daniel (1989).

Hemiancistrus is a polyphyletic genus of many unrelated forms that is likely closely related to Peckoltia (Armbruster

\footnotetext{
*Department of Biological Sciences, 101 Cary Hall, Auburn University, AL 36849-5407, USA. e-mail: (DCW) wernedc@auburn.edu; (NKL)lujannk@auburn.edu

**Department of Ichthyology, The Academy of Natural Sciences, 1900 Benjamin Franklin Parkway, Philadelphia, PA 19103-1195, USA. e-mail:sabaj@acnatsci.org

***Department of Biological Sciences, 331 Funchess, Auburn University, AL 36849-5407, USA. e-mail: armbrjw@auburn.edu
} 


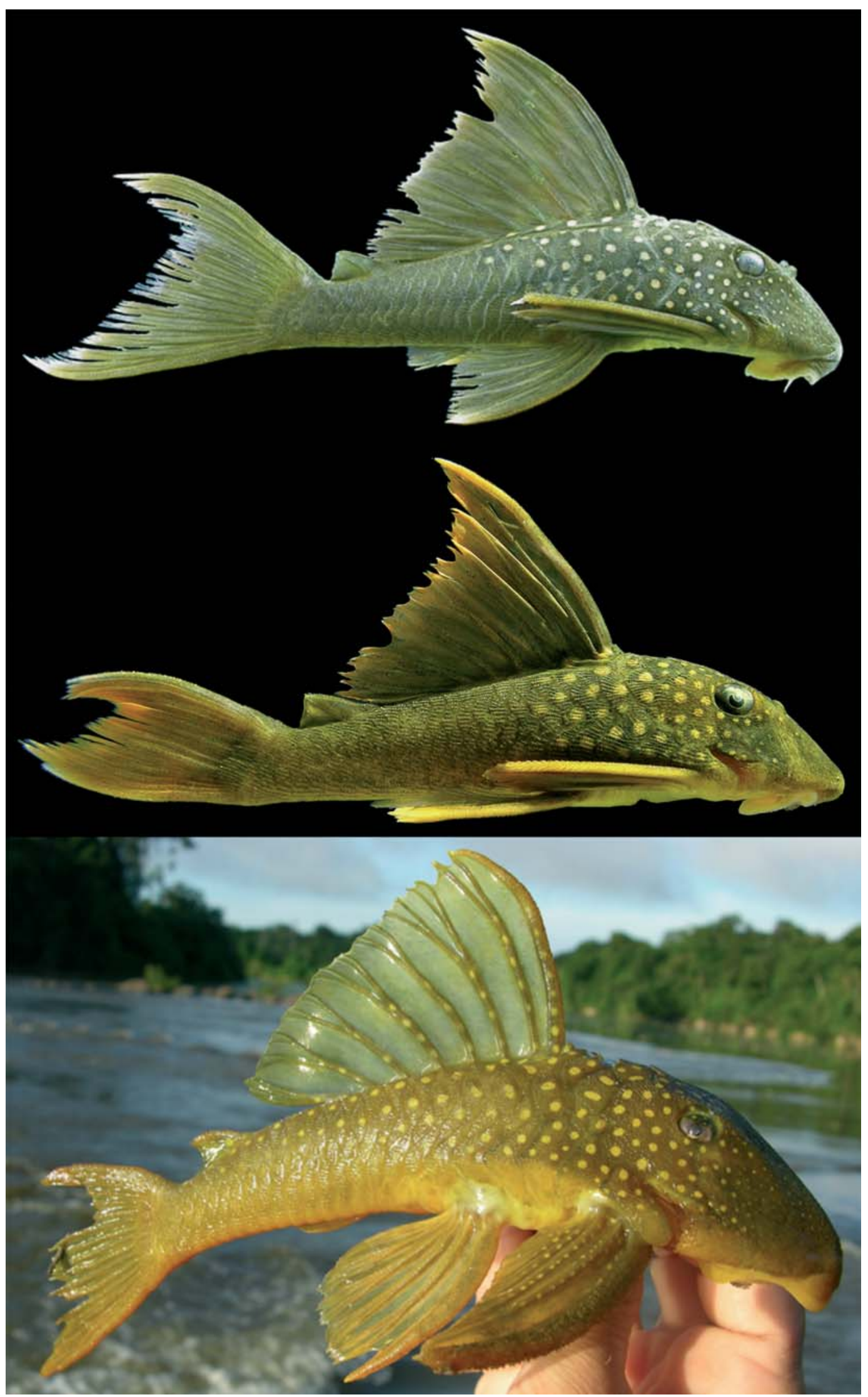

Fig. 1. Live specimens of a: Baryancistrus demantoides, adult, AUM 42034, paratype, $96.3 \mathrm{~mm}$ SL; b: B. demantoides, juvenile, MCNG 54031, paratype, 54.1 mm SL; c: Hemiancistrus subviridis, AUM 42933, 146.9 mm SL. Photos by M.H. Sabaj. 
2004). In general, species of ancistrins that have a sickleshaped opercle, dark or light spots on the body or fins or an entirely dark body, and lack the synapomorphies of the other genera of the Ancistrini are placed in Hemiancistrus and species with dorsal saddles are placed in Peckoltia (Cardoso \& Lucinda 2003, Armbruster 2004, Armbruster \& Werneke 2005). The new species described herein lacks the synapomorphies for the other genera of the Ancistrini and has spots; hence its placement in Hemiancistrus. Baryancistrus demantoides and Hemiancistrus subviridis are described herein, and their unique color pattern is commented upon.

\section{Material and Methods}

Counts and measurements follow Armbruster (2003). Museum acronyms follow Leviton et al. (1985). Specimens were cleared and stained for examination of bone and cartilage following the methods of Taylor \& Van Dyke (1985). Names of plate rows follow Schaefer (1997). The following are abbreviations used in the text: $\mathrm{D}=$ distance, $\mathrm{Dia}=$ diameter, $\mathrm{Dp}=$ depth, $\mathrm{dr}=$ drainage, $\mathrm{L}=$ length, $\mathrm{W}=$ width. When present in materials examined first number in parentheses represents the number of specimens measured followed by the range of standard lengths of the specimens. Specimens were sampled broadly within the type series and the non-types, but given the large number of specimens available, not all specimens were measured or examined for meristics. Measured specimens have numbered points inserted into their gill openings. Comparative specimens examined are listed in Armbruster $(2003,2004)$ and Armbruster \& Werneke (2005) and also include: Baryancistrus longipinnis MCZ 29051, holotype, and MNRJ 19340, 1, and B. niveatus MNHN A9353, 1, syntypes; MNHN A-9454, syntypes; MNRJ 19344, 12; MCP 28971, 1; MCP 28972, 1; and MCP 28970, 2. Dorsaladipose distance and dorsal-anal distance were excluded from $B$. demantoides because the dorsal fin is connected to the adipose fin and the measurements are either redundant or impractical.

Gut contents were examined by dissecting the viscera from the peritoneal cavity of two Baryancistrus demantoides and three Hemiancistrus subviridis. The viscera were removed as a unit by cutting the esophagus immediately posterior to the ventral processes of the complex centrum, and the posterior intestinal tract immediately anterior to anus. Anterior 100 $\mathrm{mm}$ of gut was dissected to expose gut contents.

\section{Results}

\section{Baryancistrus demantoides, new species}

Figs. 1a,b and 2

Holotype. MCNG 54029, 150.5 mm SL, Venezuela, Amazonas, río Orinoco drainage, río Ventuari near ornamental fish market in river, $04.07565^{\circ},-066.89285^{\circ}, 3 \mathrm{Apr} 2005$, N. K. Lujan, M. Arce, E. L. Richmond, M. B. Grant, \& T.E. Wesley.

Paratypes. Venezuela, Amazonas, río Orinoco drainage: AUM
37974,1 (1, $131.5 \mathrm{~mm}$ SL), río Guapuchi first major riffle complex, $04.11667^{\circ},-066.76667^{\circ}, 16$ Apr 2003, N. K. Lujan \& O. León. ANSP 180226, 1 (1, 85.5 mm SL), AUM 42034, 1 (1,96.3 $\mathrm{mm} \mathrm{SL})$, MCNG 54030, 1 (1, $50.6 \mathrm{~mm} \mathrm{SL})$, río Orinoco, Cucue Amerindian Village $60 \mathrm{~km}$ E of San Fernando de Atabapo, $03.97380^{\circ},-067.15821^{\circ}, 3$ Apr 2004, M. H. Sabaj, N. K. Lujan, D. C. Werneke, \& L. S. de Souza. ANSP 180227, 1 (1, $88.3 \mathrm{~mm}$ SL), AUM 42204, 1 (1, $124.8 \mathrm{~mm} \mathrm{SL})$, same data as holotype. ANSP 180228, 1 (1, $115.4 \mathrm{~mm} \mathrm{SL})$, AUM 42169, 2 (2, 103.8$118.3 \mathrm{~mm} \mathrm{SL}), 1 \mathrm{c} \& s, \mathrm{MCNG} 54031,1$ (1, $54.1 \mathrm{~mm} \mathrm{SL})$, río Orinoco $60 \mathrm{~km}$ E of San Fernando de Atabapo, 03.97401 ${ }^{\circ}$, $067.16276^{\circ}, 3$ Mar 2005, N. K. Lujan, D. C. Werneke, M. H. Sabaj, \& M. Arce.

Diagnosis. Baryancistrus demantoides can be distinguished from all other loricariids except Baryancistrus niveatus, Parancistrus, and Spectracanthicus by having the dorsal and adipose fins connected by an expanded posterior section of the dorsal-fin membrane. Baryancistrus demantoides can be separated from the other species with connected dorsal fins by having a yellow-olive color with white or creamcolored spots (vs. typically dark with white, gold, or no spots); from other Baryancistrus with the dorsal fins connected by having the spots only on the anterior portion on the body (vs. all over), from Parancistrus by not being dorsoventrally flattened, and from Spectracanthicus by having greater than 30 teeth per jaw ramus ( $v s$. less than 25 ). There is one other described species of Baryancistrus (B. longipinnis) that has an expanded posterior membrane of the dorsal fin, but the membrane does not connect to the adipose fin as in $B$. demantoides and B. longipinnis lacks light spots.

Description. A member of Subfamily Hypostominae, Tribe Ancistrini as diagnosed by Armbruster (2004). Morphometrics presented in Table 1. Medium-sized loricariids with largest specimen $150.5 \mathrm{~mm}$ SL. Body stout. Head sloped from snout at approximate $40^{\circ}$ angle to point above anterior portion of eye. Dorsal profile from point above anterior portion of eye ascending slightly to anterior insertion of dorsal fin. Dorsal profile from anterior insertion of dorsal fin decreasing to insertion of dorsal procurrent caudal rays then ascending to caudal fin. Body depth greatest below origin of dorsal fin. Ventral profile straight to caudal fin. Caudal peduncle triangular in cross section with dorsal surface flattened. Body widest at origin of pectoral fins, narrowest at base of caudal fin. Snout rounded when viewed from above.

Eyes moderately sized. Iris with dorsal flap. Interorbital space flat. Slight ridge present between anterodorsal margin of orbit and nares. Supraoccipital pointed posteriorly, slightly or not elevated above nuchal plate. Infraorbitals, frontal, nasal, pterotic, and supraoccipital supporting odontodes. Preopercle and opercle without odontodes.

Lips covered with short, wide papillae. Lower lip wide, upper lip narrow. Maxillary barbel only barbel present, reaching posteriorly more than one-third of distance to gill opening. 


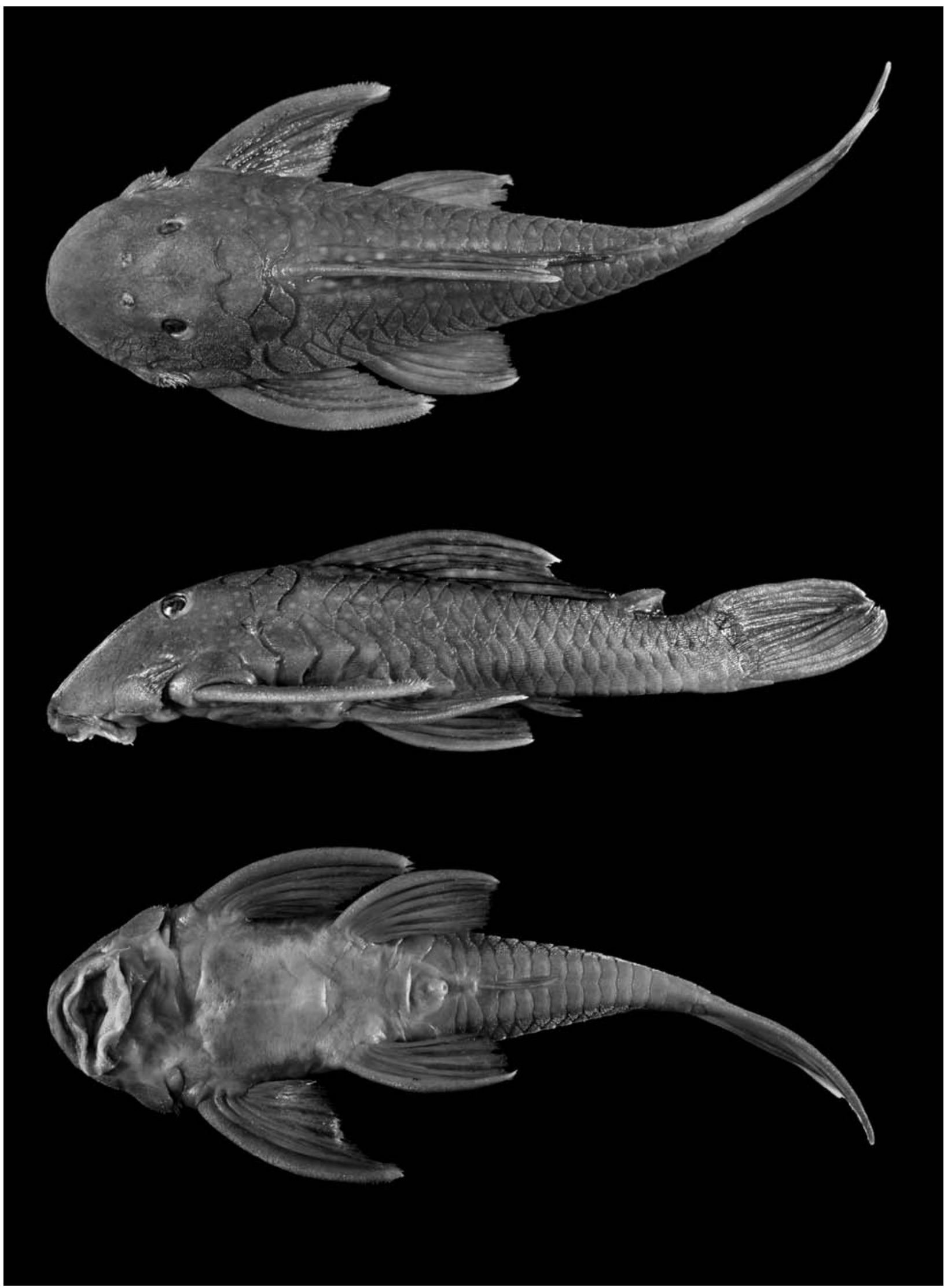

Fig. 2. Baryancistrus demantoides MCNG 54029, $150.5 \mathrm{~mm}$ SL; holotype, dorsal, lateral, and ventral views. Photos by D.C. Werneke. 
Median plates 24-26 $($ mode $=25)$. Plates unkeeled. Five caudal peduncle plate rows. Plates on all surfaces of body except for anteroventral margin of snout and most of ventral surface. Some small embedded plates present ventral to pectoral-fin girdle. Evertible cheek plates supporting hypertrophied odontodes that can be everted perpendicular to head. Cheek odontodes 35-73 (median $=53$, mode unavailable no counts occurred more than once), longest evertible cheek odontode reaching to cleithrum. Hypertrophied cheek odontodes relatively weak. Slightly longer odontodes present along dorsal-, adipose-, pelvic-, caudal-, and pectoral-fin spines.

Dorsal fin II, 7; dorsal spinelet V-shaped, dorsal-fin locking mechanism present, last ray of dorsal fin reaching insertion of adipose spine when adpressed, membranous connection present between last dorsal ray and body to preadipose plate. Adipose fin with single preadipose plate and moderately long spine. Caudal fin i,14.i; caudal fin forked, ventral lobe longer than dorsal lobe, dorsal procurrent caudal rays four, ventral procurrent caudal rays four. Pectoral fin I,6; pectoral-fin spine reaching beyond insertion of pelvic-fin spine when adpressed ventral to pelvic fin. Pelvic fin i,5; pelvic-fin spine extending beyond base of anal fin when adpressed. Anal fin i,4; anal-fin spine slightly shorter than first ray.

Teeth bicuspid with lateral lobe three-quarters length of medial lobe and distal tip of lateral cusp one-half width of tip of medial cusp. Worn teeth with lobes approaching equal lengths. Left dentary teeth $34-51($ mode $=46)$. Left premaxillary teeth $37-54($ mode $=43)$.

Color in life. Adults with yellow-olive ground color on body and fins. Head, anterior sides to base of last dorsal-fin ray, and skin covering dorsal-fin base with distinct round white to cream-colored spots. Spots largest and more remotely spaced on anterior body, becoming gradually smaller and more closely spaced towards and onto snout. Fins usually uniformly yellow-olive. Dorsal fin occasionally with faint light spots on basal portions of membranes and sometimes rays. Juveniles often with orange-olive ground color, golden spots, and distal margins of dorsal and caudal fins bright orange.

Color in alcohol. Adults with head, sides, and fins nearly uniform gray-brown; plated ventral surfaces tan and naked abdominal region white to cream-colored (without markings). Faint round spots slightly lighter than ground color usually evident on posterior portion of head (between, below, and posterior to eyes) and anterior sides to insertion of last dorsal-fin ray. Light spots larger on sides and more remotely spaced; one to three spots per lateral plate anterior to dorsal fin and usually one spot per plate below dorsal-fin base (excepting large plates in ventral plate row). Light spots on posterior head smaller, more closely spaced, and often scarcely evident. Fin rays and membranes darkly pigmented with melanophores. Dorsal fin usually with faint roundish light spots largely restricted to basal half of membranes and sometimes fin rays. Pectoral and pelvic fins sometimes with faint round- ish light spots largely restricted to basal portion of fins. Juvenile coloration similar to adults except light spots more obvious on anterior sides and head (but usually lacking from fins).

Range. Baryancistrus demantoides is known from the río Orinoco at its confluence with the río Ventuari and the lower río Ventuari upstream into the río Guapuchi (Fig. 3).

Etymology. The specific name refers to a demantoid, a type of garnet that ranges in color from yellowish green to brownish green and it is in reference to the color of the fish. The word comes from the obsolete German word diemant meaning diamond and the Greek suffix -oïdes meaning to resemble.

Gut morphology and ecology. Gastrointestinal tract brown with yellow-green fat deposits, loosely attached to intestinal wall. Esophagus turns $90^{\circ}$ toward right upon entering peritoneal cavity, extends straight to right for short distance, turns $90^{\circ}$ toward posterior before transitioning into proximal (cardiac) stomach. Cardiac stomach extends posteriorly for two thirds of length then transitions into distal (pyloric) stomach by making a $180^{\circ}$ turn such that pyloric portion exits anteriorly and lies to right of cardiac portion. Proximal intestines exit the anterior-facing pyloric stomach, turn $180^{\circ}$ to cross dorsally over esophagus, then continuing posteriorly towards anus. Near the anus, the proximal and distal ends of intestines begin a parallel, clockwise spiral to the left with coils accruing ventral to stomach and esophagus. Proximal intestines spiral clockwise for half of entire intestinal length, turn $180^{\circ}$ at their middle, then distal portion spirals back toward anus. Length of intestines and stomach from 15-21 times SL. External diameter of intestines ranges from 1-2 mm.

Baryancistrus demantoides was found exclusively among granite rocks in flowing water. Gut contents of two individuals consisted of a mixed brown organic and mineral matrix in

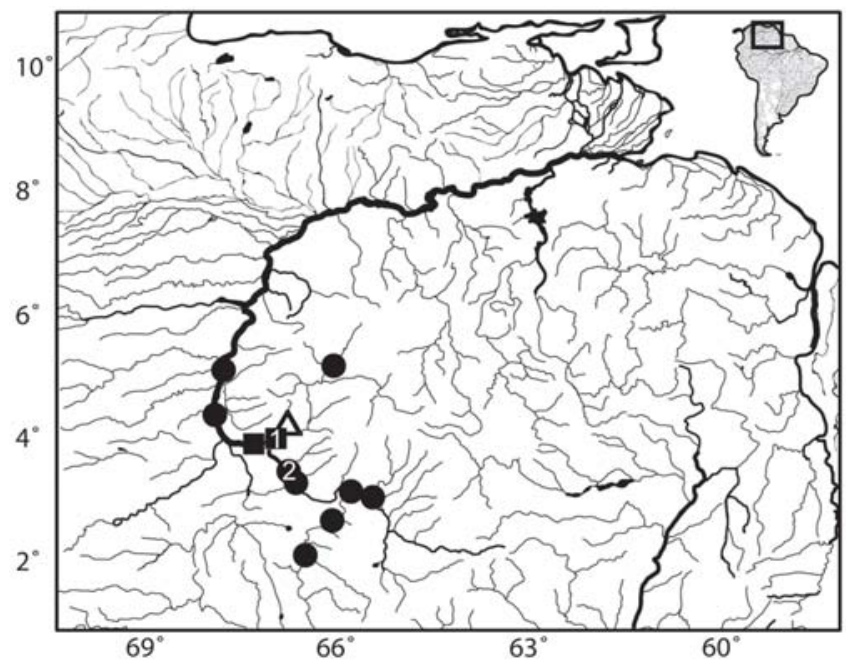

Fig. 3. Localities of Baryancistrus demantoides (triangle), Hemiancistrus subviridis (dots), and both species (squares). 1 is the type locality of $B$. demantoides and 2 is the type locality of $H$. subviridis. 
which the only identifiable constituents were small tufts of filamentous algae attached to tiny grains of granite. Like most other ancistrins in the region, it likely feeds by scraping periphyton and indiscriminately ingesting both the sediment matrix deposited from the water column and the attached algae and benthic macroinvertebrates that often live within the sediment layers.

\section{Hemiancistrus subviridis, new species}

Figs. 1c and 4

Holotype. MCNG 54032, 133.5 mm SL, Venezuela, Amazonas, río Orinoco $117 \mathrm{~km} \mathrm{~W}$ of La Esmeralda, 03.28998 ${ }^{\circ},-066.60004^{\circ}$, 29 Mar 2005, N. K. Lujan, M. Arce, T. E. Wesley, M. B. Grant, E. L. Richmond, J. Valadez, D. Brooks, F. Brito, \& O. Santaella. Paratypes. VENEZUELA, Amazonas, río Orinoco drainage: ANSP 162167, 1 (1, 149.5 mm SL), río Orinoco at rocks $1 \mathrm{~km}$ above La Esmeralda, 14 Mar 1987, W. G. Saul, J. Fernandez, O. Castillo, \& M. E. Antonio. ANSP 162178, 1 (1, $134.8 \mathrm{~mm} \mathrm{SL})$, río Orinoco, backwater behind sandy beach $1 / 2 \mathrm{hr}$ upstream from Isla Tremblador, 10 Mar 1987, W. G. Saul, H. Lopez, J. Fernandez, O. Castillo, M. E. Antonio, \& J. Moreno. ANSP 180229, 4 (1, 93.4 mm SL), AUM 39228, 4 (1, 106.9 mm SL), MCNG 54033,3 (1, 82.3 mm SL), río Orinoco, Cucue Amerindian Village $60 \mathrm{~km}$ E of San Fernando de Atabapo, 03.97380 , 067.15821 ${ }^{\circ}, 3$ Apr 2004, M. H. Sabaj, N. K. Lujan, D. C. Werneke, \& L. S. deSouza. AUM 39231, 2, 1c\&s, río Ventuari beach across the river from Picua Village $34 \mathrm{~km}$ ENE of Macuruco $104 \mathrm{~km}$ E of San Fernando de Atabapo, 04.11534, $-066.76457^{\circ}, 5$ Apr 2004, M. H. Sabaj, N. K. Lujan, D. C. Werneke, L. S. de Souza, \& O. León. ANSP 180230, 2 (2, 77.2-103.6 mm SL), AUM 39244, 2 (2, 89.4-105.6 mm SL), MCNG 54034, 2 (2, $58.2-103.7 \mathrm{~mm} \mathrm{SL}$ ), río Ventuari $23 \mathrm{~km} \mathrm{NE}$ of Macuruco $94 \mathrm{~km}$ E of San Fernando de Atabapo, $04.08042^{\circ},-066.86513^{\circ}, 5$ Apr 2004, N. K. Lujan, D. C. Werneke, M. H. Sabaj, L. S. deSouza, \& O. León. ANSP 180231, 2 (2, 97.4-125.2 mm SL), AUM39283, 3 (3, 51.5-121.0 mm SL), MCNG 54035, 2 (2, 57.3-109.0 mm SL), río Parucito at raudales Salomon $2.7 \mathrm{~km}$ NE of San Juan de Manapiare, $05.34637^{\circ},-066.03347^{\circ}, 16$ Apr 2004, D. C. Werneke, N. K. Lujan, \& O. León. ANSP 180236, 3 (1, 121.0 mm SL), AUM 42117,3 (1, 134.4 mm SL), MCNG 54036, 1, same data as holotype. ANSP 180233, 3 (1, 60.3 mm SL), AUM 42124, $3(1,115.3 \mathrm{~mm} \mathrm{SL}), \mathrm{MCNG} 54037,2$ (1,39.0 mm SL), río Orinoco $33.9 \mathrm{~km} \mathrm{~W}$ of La Esmeralda at Punto Piaroa, 03.14744 ${ }^{\circ}$, $065.85381^{\circ}, 28$ Mar 2005, N. K. Lujan, M. Arce, T. E. Wesley, M. B. Grant, E. L. Richmond, J. Valadez, \& D. Brooks. AUM 42140, 2 (2, 132.8-134.2 mm SL), Pasaganado $38 \mathrm{~km} \mathrm{~N}$ of San Fernando de Atabapo, $04.38442^{\circ},-067.77444^{\circ}, 1$ Mar 2005, N. K. Lujan, D. C. Werneke, M. H. Sabaj, M. Arce, \& T. E. Wesley. ANSP 180232, 2 (1, $99.9 \mathrm{~mm} \mathrm{SL})$, AUM 42146, 2 (1, $108.9 \mathrm{~mm}$ $\mathrm{SL})$, río Ventuari $163 \mathrm{~km} \mathrm{SE}$ of Samariapo, $04.05736^{\circ},-066.93257^{\circ}$, 1 Apr 2005, N. K. Lujan, M. Arce, T. E. Wesley, E. L. Richmond, \& M. B. Grant. AUM 42174, 2 (2, 79.7-100.7 mm SL), río Orinoco $60 \mathrm{~km}$ E of San Fernando de Atabapo, 03.97401 ${ }^{\circ}$, 067.16276, 3 Mar 2005, N. K. Lujan, D. C. Werneke, M. H. Sabaj, \& M.Arce.AUM 42212, 2 (2,36.9-108.8 mm SL), MCNG
54038, 2 (1, $93.8 \mathrm{~mm} \mathrm{SL})$, río Ventuari near ornamental fish market in river, $04.07565^{\circ},-066.89285^{\circ}, 3$ Apr 2005 , N. K. Lujan, M. Arce, E. L. Richmond, M. B. Grant, \& T. E. Wesley. AUM 42929, 1 (1, $108.3 \mathrm{~mm} \mathrm{SL})$, río Orinoco at Macuruco landing, $03.95820^{\circ},-067.03210^{\circ}, 30$ Mar 2005, N. K. Lujan, M. Arce, E. L. Richmond, M. B. Grant, J. Valadez, D. Brooks, \& T. E. Wesley. AUM 42931, 1 (1, 65.0 mm SL), río Orinoco beach and bedrock outcropping $50 \mathrm{~km}$ E of San Fernando de Atabapo, 03.97029 -067.25506, 2 Mar 2005, N. K. Lujan, D. C. Werneke, M. H. Sabaj, M. Arce, R. Betancur, \& T. E. Wesley. AUM 42932, 1 (1, $140.2 \mathrm{~mm} \mathrm{SL}$ ), río Orinoco island W of Puerto Venado $4.5 \mathrm{~km} \mathrm{~S}$ of Samariapo $56.5 \mathrm{~km} \mathrm{SE}$ of Puerto Ayacucho, 05.20708 ${ }^{\circ}$, $067.80900^{\circ}, 28$ Feb 2005 , N. K. Lujan, D. C. Werneke, M. H. Sabaj, M. Arce, R. Betancur, and T. E. Wesley. MCNG 30361, $1(1,112.0 \mathrm{~mm} \mathrm{SL})$, río Orinoco in front of Macuruco, $5 \mathrm{Aug}$ 1994, A. Barbarino, I. Lopez, \& R. Berrios.

Non-types. VENEZUELA, Amazonas, río Casiquiare drainage: AUM 42201, 1 (1, $73.3 \mathrm{~mm} \mathrm{SL})$, río Casiquiare $153 \mathrm{~km}$ NE of San Carlos de río Negro, $02.79877^{\circ},-066.00652^{\circ}, 24$ Mar 2005. ANSP 180234, 1 (1, $38.3 \mathrm{~mm} \mathrm{SL})$, AUM 42930, 1 (1, 89.4 mm SL), MCNG 54039, 1 (1, 51.7 mm SL), río Casiquiare left bank upstream from mouth of río Siapa, $02.15570^{\circ},-066.46377^{\circ}, 19-22$ Mar 2005. ANSP 180235, 2, AUM 42933, 2 (1, 146.9 mm SL), río Casiquiare bedrock riffle and outcrop $74.6 \mathrm{~km} \mathrm{NE}$ of San Carlos de río Negro, $02.36280^{\circ},-066,56483^{\circ}, 9$ Mar 2005. MCNG 12362, 2 (2, 62.1-65.9 mm SL), raudal Cabarua approximately $5 \mathrm{~km} \mathrm{~N}$ of confluence with río Siapa, $02.11667^{\circ},-066.46667^{\circ}, 18$ Apr 1985.

Diagnosis. Hemiancistrus subviridis can be separated from all other hypostomines except Baryancistrus demantoides by having a light gold-olive base color in life with goldenyellow spots, and from $B$. demantoides by lacking a membranous connection between the dorsal and adipose fins and by having 9-29 left dentary teeth (vs. 34-51). Hemiancistrus subviridis when preserved is very similar to the sympatric $H$. guahiborum from which it differs by lacking an orange band at the edge of its dorsal and caudal fins and by having 9-29 left dentary teeth ( $v s .28-72)$. The only other species of Hemiancistrus with light spots are $H$. chlorostictos, $H$. fuliginosus, $H$. macrops, $H$. meizospilos, and $H$. votouro. In addition to the light gold-olive base color ( $v s$. dark gray base color), H. subviridis can be separated from $H$. chlorostictos, $H$. fuliginosus, H. meizospilos, and $H$. votouro by having a forked caudal fin ( $v$ s. an emarginate caudal fin) and by having 9-29 left dentary teeth (vs. 41-86); and from H. macrops by having the light spots restricted to the anterior half of the body ( $v s$. all over).

In addition, Hemiancistrus subviridis can be separated from all ancistrins except Baryancistrus, other Hemiancistrus, Hypancistrus, Panaque, Parancistrus, Peckoltia, and some Pseudancistrus by lacking odontodes on the opercle; from Ancistrus, Dekeyseria, Lasiancistrus, Neblinichthys, and Pseudolithoxus by having five rows of plates on the caudal peduncle (vs. three); from Hopliancistrus by having more than 10 relatively straight hypertrophied odontodes on the evertible cheek plates (vs. usually less than five strongly recurved hypertrophied odontodes); from Exastilithoxus and 


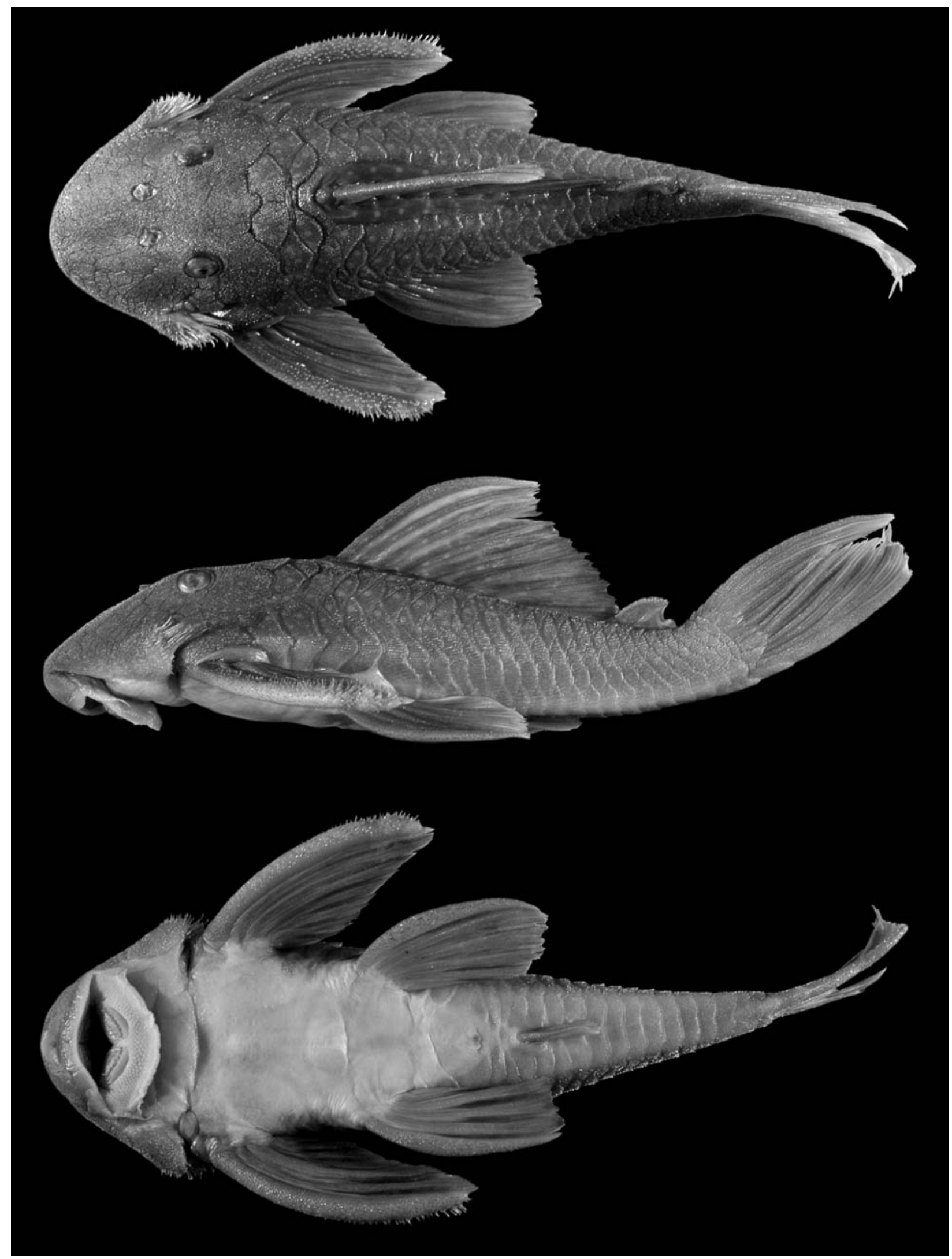

Fig. 4. Hemiancistrus subviridis MCNG 54032, $133.5 \mathrm{~mm}$ SL; holotype, dorsal, lateral, and ventral views. Photos by D.C. Werneke. 
Table 1. Morphometrics of Baryancistrus demantoides $(\mathrm{N}=11)$ and Hemiancistrus subviridis $(\mathrm{N}=52$ except dorsal-spine length $\mathrm{N}=49$ ). 'Landmarks' represents the two points between which the measurements were taken (from Armbruster 2003). Measurements are ratios of SL (predorsal 1. to pelvic-dorsal 1.) or head 1. (head-eye 1. to premaxillary tooth cup 1).

\begin{tabular}{|c|c|c|c|c|c|c|c|c|c|c|c|}
\hline \multirow[b]{2}{*}{ Landmarks } & \multirow[b]{2}{*}{ Measurement } & \multicolumn{5}{|c|}{ Baryancistrus demantoides } & \multicolumn{5}{|c|}{ H. subviridis } \\
\hline & & Average & SD & & $\operatorname{Ran}$ & & Average & SD & & $\operatorname{Ran}$ & \\
\hline $1-20$ & $\mathrm{SL}(\mathrm{mm})$ & 101.7 & 31 & 50.6 & - & 150.5 & 93.5 & 29.7 & 36.9 & - & 149.5 \\
\hline $1-10$ & Predorsal L. & 40.5 & 1.1 & 38.8 & - & 42.7 & 43.0 & 2.1 & 39.0 & - & 48.9 \\
\hline $1-7$ & Head L. & 34.7 & 1.0 & 33.2 & - & 36.4 & 36.6 & 2.1 & 32.7 & - & 41.9 \\
\hline $7-10$ & Head-dorsal L. & 6.1 & 1.0 & 4.2 & - & 7.3 & 6.5 & 1.1 & 4.0 & - & 9.4 \\
\hline $8-9$ & Cleithral W. & 29.8 & 0.7 & 29.1 & - & 31.3 & 28.0 & 3.0 & 23.1 & - & 33.1 \\
\hline $1-12$ & Head-pectoral L. & 27.7 & 0.9 & 26.3 & - & 29.1 & 29.5 & 1.8 & 24.5 & - & 34.0 \\
\hline $12-13$ & Thorax L. & 22.5 & 1.3 & 20.8 & - & 24.5 & 21.8 & 1.3 & 19.5 & - & 25.0 \\
\hline $12-29$ & Pectoral-spine L. & 34.9 & 1.2 & 32.7 & - & 36.7 & 34.0 & 2.0 & 28.8 & - & 37.7 \\
\hline $13-14$ & Abdominal L. & 23.4 & 0.9 & 22.0 & - & 24.7 & 22.9 & 2.2 & 12.1 & - & 26.7 \\
\hline $13-30$ & Pelvic-spine L. & 28.4 & 1.3 & 25.6 & - & 30.3 & 26.8 & 1.3 & 24.2 & - & 30.5 \\
\hline $14-15$ & Postanal L. & 34.8 & 1.7 & 30.7 & - & 36.6 & 34.2 & 2.0 & 29.8 & _- & 38.8 \\
\hline $14-31$ & Anal-fin spine L. & 11.7 & 1.6 & 8.0 & - & 14.0 & 10.2 & 1.4 & 7.3 & - & 13.3 \\
\hline $10-12$ & Dorsal-pectoral D. & 27.0 & 0.7 & 26.1 & - & 28.5 & 27.4 & 1.3 & 24.6 & - & 30.2 \\
\hline $10-11$ & Dorsal spine L. & 42.1 & 3.3 & 36.5 & - & 46.4 & 34.3 & 3.0 & 27.3 & - & 39.9 \\
\hline $10-13$ & Dorsal-pelvic D. & 24.8 & 1.6 & 22.5 & - & 27.3 & 23.3 & 1.8 & 19.3 & - & 29.5 \\
\hline $10-16$ & Dorsal-fin base L. & 44.8 & 3.2 & 35.9 & - & 47.6 & 32.8 & 1.8 & 28.6 & - & 35.7 \\
\hline $16-17$ & Dorsal-adipose D. & & & & & & 10.1 & 2.7 & 4.0 & - & 16.2 \\
\hline $17-18$ & Adipose-spine L. & 9.2 & 0.8 & 7.8 & - & 11.0 & 10.5 & 1.7 & 7.3 & - & 14.9 \\
\hline $17-19$ & Adipose-up. caudal D. & 15.2 & 0.9 & 13.7 & - & 16.6 & 15.9 & 2.3 & 11.2 & - & 23.9 \\
\hline $15-19$ & Caudal peduncle Dp. & 11.3 & 1.2 & 9.7 & - & 13.9 & 11.9 & 1.0 & 9.5 & - & 14.5 \\
\hline $15-17$ & Adipose-low. caudal D. & 22.7 & 0.9 & 21.1 & - & 24.2 & 23.4 & 1.8 & 18.7 & - & 26.8 \\
\hline $14-17$ & Adipose-anal D. & 21.4 & 0.5 & 20.4 & - & 22.0 & 18.9 & 1.5 & 15.2 & - & 21.8 \\
\hline $14-16$ & Dorsal-anal D. & & & & & & 15.3 & 0.9 & 13.5 & - & 17.8 \\
\hline $13-16$ & Pelvic-dorsal D. & 39.2 & 3.6 & 29.7 & - & 42.9 & 29.6 & 3.2 & 22.7 & - & 44.6 \\
\hline $5-7$ & Head-eye L. & 28.5 & 1.2 & 26.6 & - & 30.0 & 29.0 & 2.3 & 25.5 & - & 38.1 \\
\hline $4-5$ & Orbit Dia. & 18.6 & 2.5 & 15.2 & - & 22.5 & 17.0 & 2.2 & 11.6 & - & 23.6 \\
\hline $1-4$ & Snout L. & 66.4 & 3.1 & 61.1 & - & 71.7 & 67.1 & 3.3 & 58.2 & - & 74.2 \\
\hline $2-3$ & Internares W. & 12.5 & 1.5 & 11.0 & - & 15.7 & 11.9 & 1.3 & 8.9 & - & 15.2 \\
\hline $5-6$ & Interorbital W. & 38.5 & 3.5 & 32.8 & - & 45.9 & 35.2 & 6.1 & 26.1 & - & 50.4 \\
\hline $7-12$ & Head Dp. & 70.2 & 2.0 & 66.2 & - & 73.1 & 66.9 & 3.4 & 59.6 & - & 79.5 \\
\hline $1-24$ & Mouth L. & 47.5 & 2.9 & 43.1 & - & 51.7 & 50.5 & 3.7 & 43.6 & - & 63.6 \\
\hline $21-22$ & Mouth W. & 52.7 & 3.7 & 48.1 & - & 59.4 & 50.6 & 9.5 & 28.3 & - & 64.4 \\
\hline $22-23$ & Barbel L. & 11.5 & 1.5 & 9.6 & - & 14.6 & 9.2 & 2.4 & 3.7 & - & 13.4 \\
\hline $25-26$ & Dentary tooth cusp L. & 13.6 & 1.1 & 11.7 & - & 15.3 & 18.7 & 3.6 & 13.8 & - & 28.8 \\
\hline $27-28$ & Premax. tooth cusp L. & 14.8 & 1.9 & 11.5 & - & 17.5 & 18.2 & 3.6 & 12.8 & - & 28.4 \\
\hline
\end{tabular}

Lithoxus by having oval lips (vs. round); from Acanthicus, Chaetostoma, Cordylancistrus, Dolichancistrus, and Leptoancistrus, Leporacanthicus, Megalancistrus, and Pseudacanthicus by having seven dorsal-fin rays (vs. eight or more); from Acanthicus, Dekeyseria, Leporacanthicus, Megalancistrus, and Pseudacanthicus by lacking keels on the lateral plates; from most Pseudancistrus by lacking hypertrophied odontodes around the snout; from Pseudancistrus sidereus and P. megacephalus by having spots only anteriorly on the body ( $v s$. all over); from Baryancistrus by not having the posterior portion of the dorsal-fin membrane expanded; from Parancistrus, Spectracanthicus, and most Baryancistrus by not having the dorsal fin connected to the adipose fin; from Panaque by having viliform teeth (vS. spoon-shaped teeth or elongated teeth); from Peckoltia by having light spots (vs. dark spots or saddles); and from Hypancistrus by having the teeth of the dentary and premaxillary of equal size ( $v s$. dentary teeth longer than premaxillary teeth).

Description. A member of Subfamily Hypostominae, Tribe Ancistrini as diagnosed by Armbruster (2004). Morphometrics in Table 1. Medium-sized loricariids, largest specimen 149.5 $\mathrm{mm} \mathrm{SL}$. Body stout. Head sloped at approximate $30^{\circ}$ angle to point above anterior portion of eye. Nape ascending slightly to insertion of dorsal fin. Dorsal slope decreasing to insertion of dorsal procurrent caudal rays then ascending to caudal fin. Body depth greatest below insertion of dorsal fin. Ventral profile flat to caudal fin. Caudal peduncle triangular in cross section with dorsal surface flattened. Body widest at insertion of pectoral fins, narrowest at insertion of caudal fin. Snout rounded.

Eyes moderately sized. Iris with dorsal flap. Interorbital space flat. Slight ridge formed between anterodorsal margin of orbit and nares. Supraoccipital pointed posteriorly, not elevated above nuchal plate. Infraorbitals, frontal, nasal, pterotic, and supraoccipital supporting odontodes. Preopercle and opercle not supporting odontodes.

Lips covered with short, wide papillae. Lower lip wide, upper lip narrow. Maxillary barbel only barbel present, reaching more than one third of distance to gill opening.

Median plates 23-25 $($ mode $=24)$. Plates unkeeled. Five caudal peduncle plate rows. Plates on all surfaces of body except for small naked upside down $\mathrm{V}$-shaped wedge on the 
anteroventral margin of snout, throat, and abdomen behind pectoral. Some small embedded plates ventral to pectoral girdle and along ventromedial insertion of pectoral fin. Evertible cheek plates supporting hypertrophied odontodes that can be everted perpendicular to head. Cheek odontodes 17-74 $($ mode $=60)$. Longest evertible cheek odontode reaching cleithrum. Hypertrophied cheek odontodes relatively weak. Slightly longer odontodes present along dorsal-, adipose-, pelvic-, caudal-, and pectoral-fin spines; larger individuals with hypertrophied odontodes at tip of pectoral spine.

Dorsal fin II, 7; dorsal spinelet V-shaped, dorsal-fin locking mechanism present, last ray of dorsal fin reaching insertion of adipose spine when adpressed. Adipose fin with single preadipose plate and moderately long spine. Caudal fin i, 14,i; caudal fin forked, ventral lobe longer than dorsal lobe, dorsal procurrent caudal rays four, ventral procurrent caudal rays four. Pectoral fin I,6; pectoral-fin spine reaching beyond insertion of pelvic-fin spine when adpressed ventral to pelvic fin. Pelvic fin i,5; pelvic-fin spine extending beyond base of anal fin when adpressed. Anal fin i,4; anal-fin spine slightly shorter than first ray.

Teeth bicuspid with lateral lobe three-quarters length of medial lobe and distal tip of lateral cusp one-half width of tip of medial cusp. 9-29 left dentary teeth $($ mode $=17)$. 10-28 left premaxillary teeth $($ mode $=19)$.

Color in life. Adults with light golden-olive ground color on body and fins. Head, anterior sides and skin covering dorsalfin base with distinct round golden-yellow spots. Spots usually confined to portion of sides anterior to last dorsal-fin ray, but sometimes continuing on dorsolateral plates to below adipose fin or slightly beyond. Spots largest and more remotely spaced on anterior body below dorsal fin, becoming gradually smaller and more closely spaced towards and onto snout. Dorsal fin with distinct golden-yellow spots largely confined to basal two-thirds of spine and rays (lacking from membranes and distal portions of spine and rays). Pectoral fin with smaller golden-yellow spots largely confined to basal one-half to basal three-quarters of rays.

Color in alcohol. Adults with head, sides and fins nearly uniform light to medium gray-brown (becoming lighter posteriorly); plated undersurfaces tan, naked abdominal region white to cream-colored (without markings). Light spots on head and anterior sides clearly evident; light spots on head smaller, more numerous, and more tightly spaced; lateral plates anterior to dorsal fin usually with two to five light spots per plate; light spots also evident on skin along dorsal-fin insertion. Light spots on dorsal fin largely restricted to basal two-thirds of spine and rays, lacking on membranes. Light spots usually lacking on paired fins but sometimes evident on anterior membranes of pectoral fin. Juvenile coloration more or less as described for adults except light spots in fins lacking.

Range. Hemiancistrus subviridis is known from the río Orinoco upstream of Atures rapids to río Iguapo, the río
Ventuari, and the río Casiquiare upstream of the río Siapa (Fig. 3).

Etymology. From the Latin subviridis meaning greenish in reference to the olive base color in life.

Gut morphology and ecology. Gastrointestinal tract brown with yellow-green fat deposits, loosely attached to intestinal wall. Esophagus turns $90^{\circ}$ toward right upon entering peritoneal cavity, extends straight to right for short distance, turns $90^{\circ}$ toward posterior before transitioning into proximal (cardiac) stomach. Cardiac stomach extends posteriorly for two thirds of length then transitions into distal (pyloric) stomach by making a $180^{\circ}$ turn such that pyloric portion exits anteriorly and lies to right of cardiac portion. Total length of stomach approximately $15 \mathrm{~mm}$. Proximal intestines exit the anterior-facing pyloric stomach, turn $180^{\circ}$ to cross dorsally over esophagus, then continuing posteriorly towards anus. Near the anus, the proximal and distal ends of intestines begin a parallel, clockwise spiral toward the left with coils accruing ventral toward stomach and esophagus. Proximal intestines spiral clockwise for half of entire intestinal length, turn $180^{\circ}$ at their middle, then distal portion spirals back to anus. Length of intestines and stomach from 15-17 times SL. External diameter of intestines ranges from 1-2 $\mathrm{mm}$.

Hemiancistrus subviridis were most frequently encountered in cracks and interstitial spaces of granitic rocks in flow. Gut contents of all individuals consisted largely of small grained $(<0.001 \mathrm{~mm}$ diameter $)$ mineral/organic matrix resembling clay, with some larger ( $\sim 1.0 \mathrm{~mm}$ diameter $)$ grains resembling silica sand. Organic material embedded in matrix of one individual (AUM 39283) included pieces of a moss-like nonvascular plant (Bryophyta), intact mayfly larvae (Ephemeroptera), midge larvae (Chironomidae), unidentified fly larvae (Diptera), a clump of filamentous algae, a piece of lignified vascular plant, and an ingested tooth of presumed endogenous origin. Organic components of diet in AUM 42140 consisted of unidentifiable pieces of insect exoskeleton, pieces of unidentifiable plant matter, and ingested teeth of presumed endogenous origin $(n=2)$. The only identifiable organic components in anterior gut of AUM 42124 were ingested teeth of presumed endogenous origin $(n=13)$.

\section{Discussion}

It is common to find loricariid species of different genera with similar color patterns at a particular locality. For example, in the río Ventuari there are several species that are black with white spots (Lasiancistrus schomburgkii, Leporacanthicus aff. galaxias, two undescribed species of Hypancistrus similar to $H$. inspector, and Pseudolithoxus anthrax) and several species that are tan with black spots (Lasiancistrus sp., Leporacanthicus triactis, and Pseudolithoxus dumus). In ways, this makes the convergence in coloration between Baryancistrus demantoides and Hemiancistrus subviridis unremarkable; however, the olive coloration of these species 
is fairly unique among loricariids, and no other loricariids are known to have an olive base color with cream-colored or golden-yellow spots. A similar green color is found in Acestridium dichromum; however, A. dichromum is capable of changing its base color to better match its surroundings with the green color present when the fish rest on plants, presumably for camouflage (Retzer et al. 1999). It is unknown what purpose the green coloration serves in the ancistrins as the fishes were not collected from green substrates and the fishes are not associated with vegetation.

Coloration in preserved specimens of Hemiancistrus subviridis is similar to that in Baryancistrus demantoides, except $H$. subviridis has a somewhat lighter ground color (light to medium gray-brown vs. medium gray-brown in $B$. demantoides), more light spots per lateral plate anterior to the dorsal fin (two to five $v s$. one to three in B. demantoides), light spots on skin along the dorsal-fin insertion ( $v s$. lacking in B. demantoides), and light spots on the dorsal fin largely restricted to basal two-thirds of the spine and rays in adults ( $v s$. more liberally distributed on basal portions of dorsal-fin spine, rays and membranes in adult $B$. demantoides).

\section{Acknowledgements}

This project represents part of Planetary Biodiversity Inventory: All Catfish Species (Siluriformes) - Phase I of an Inventory of the Otophysi, a five year grant through the US National Science Foundation to describe all species of catfishes (NSF DEB-0315963) and NSF grant DEB-0107751 to JWA. We express our deepest appreciation to D. Taphorn and O. León for their invaluable help in obtaining permits, logistical support, aiding in fieldwork, and loan of materials. Additional thanks to M. Arce, R. Betancur, A. Luna, R. Pajua, L. de Souza, T. Wesley, M. Grant, E. Richmond, J. Valadez, D. Brooks, F. Brito, L. Camico, and O. Santa Ella for aid in collecting specimens.

\section{Literature Cited}

Armbruster, J. W. 2003. Peckoltia sabaji, a new species from the Guyana Shield (Siluriformes: Loricariidae). Zootaxa, 344: $1-12$.
Armbruster, J. W. 2004. Phylogenetic relationships of the suckermouth armoured catfishes (Loricariidae) with emphasis on the Hypostominae and the Ancistrinae. Zoological Journal of the Linnean Society, 141: 1-80.

Armbruster, J. W. \& D. C. Werneke. 2005. Peckoltia cavatica, a new loricariid catfish from Guyana and a redescription of P. braueri (Eigenmann 1912) (Siluriformes). Zootaxa, 882: 1-14.

Cardoso, A. R. \& P. H. F. Lucinda. 2003. Three new species of Hemiancistrus (Teleostei: Siluriformes: Loricariidae) from the rio Tocantins basin with comments on the genus. Ichthyological Exploration of Freshwaters, 14: 73-84.

Leviton, A. E., R. H. Gibbs Jr., E. Heal \& H. E. Dawson. 1985. Standards in herpetology and ichthyology: Part I. Standard symbolic codes for institutional resource collections in herpetology and ichthyology. Copeia, 1985: 802-832.

Rapp Py-Daniel, L. H. 1989. Redescription of Parancistrus aurantiacus (Castelnau,1855) and preliminary establishment of two new genera: Baryancistrus and Oligancistrus (Siluriformes, Loricariidae). Cybium, 13: 235-246.

Retzer, M.E., L.G. Nico \& F. Provenzano R. 1999. Two new species of Acestridium (Siluriformes, Loricariidae) from southern Venezuela, with observations on camouflage and color change. Ichthyological Exploration of Freshwaters, 10:313-326.

Schaefer, S.A. 1997. The neotropical cascudinhos: systematics and biogeography of the Otocinclus catfishes (Siluriformes: Loricariidae). Proceedings of the Academy of Natural Sciences of Philadelphia, 148: 1-120.

Schraml, E. \& F. Schafer. 2004. Loricariidae all L-Welse / all Lnumbers. Verlag A.C.S. GmbH, Rodgau. 271p.

Taylor, W. R. \& G. C. Van Dyke. 1985. Revised procedures for staining and clearing small fishes and other vertebrates for bone and cartilage study. Cybium, 9: 107-119.

Received July 2005 Accepted November 2005 